\title{
Hydropower generation in future climate scenarios
}

\author{
Ieda Geriberto Hidalgo a,*, Javier Paredes-Arquiola ${ }^{\mathrm{b}}$, Joaquin Andreu ${ }^{\mathrm{b}}$, Nestor Lerma-Elvira ${ }^{\mathrm{b}}$, \\ Joao Eduardo Goncalves Lopes ${ }^{c}$, Francesco Cioffi ${ }^{\mathrm{d}}$ \\ a School of Technology and School of Mechanical Engineering, Department of Energy, State University of Campinas, São Paulo, Brazil \\ ${ }^{\mathrm{b}}$ School of Civil Engineering, Instituto de Ingenieria del Agua y Medio Ambiente, Universitat Politecnica de Valencia, Valencia, Spain \\ c Polytechnic School, Department of Hydraulic and Sanitary Engineering, University of Sao Paulo, São Paulo, Brazil \\ d School of Civil Engineering, Department of Civil, Building and Environmental Engineering, Sapienza University of Roma, Roma, Italy
}

\section{A R T I C L E I N F O}

\section{Article history:}

Received 27 August 2020

Revised 13 October 2020

Accepted 27 October 2020

Available online xxxx

\section{Keywords:}

Hydroelectric plants

Water resources

Energy resources

Hydrological model

Hydropower model

Climate variations

\begin{abstract}
A B S T R A C T
Knowledge on the effects of climate change in a system can contribute to the better management of its water and energy resources. This study evaluates the consequences of alterations in the rainfall and temperature patterns for a hydroelectric plant. The methodology adopted consists of four steps. First, a hydrological model is developed for the chosen basin following a semi-distributed and conceptual approach. The hydrological model is calibrated utilizing the optimization algorithm Shuffled Complex Evolution - University of Arizona (SCE-UA) and then validated. Secondly, a hydropower model is developed for a hydroelectric plant of the chosen basin. The hydropower model is adjusted to the physical characteristics of the plant. Thirdly, future climate scenarios are extracted from the literature for the studied area. These scenarios include quantitative and seasonal climate variations, as well as different initial reservoir levels. Fourth, the hydrological-hydropower model is simulated for 52 scenarios and the impact of changes in the rainfall and temperature patterns for hydropower generation is evaluated. For each scenario, the water storage in the reservoir and energy produced by the plant are analyzed. The financial impact for extreme scenarios is presented. The methodology is applied to the Três Marias hydroelectric plant at the upper São Francisco river basin (Brazil) and it can be replicated to any other hydropower system. The results show that extreme positive values predicted for rainfall will likely not cause issues to the plant, considering a moderate rise in temperature. However, negative predictions for rainfall, regardless of changes in temperature, should be an alert to the authorities responsible for water and energy resources management.
\end{abstract}

(c) 2020 International Energy Initiative. Published by Elsevier Inc. All rights reserved.

\section{Introduction}

Brazil is among the world's largest hydropower producers alongside China, Canada, and United States. Its total installed capacity is $>172,000$ MW of which almost 110,000 MW from hydroelectric plants. Fossil, wind, biomass, solar, and nuclear sources complement hydropower generation with installed capacity of $16.83 \%, 8.96 \%, 8.71 \%, 1.66 \%$, and $1.14 \%$, respectively (ANEEL, 2019).

The Brazilian hydropower system is interconnected in terms of generation and transmission of energy. Most of its plants have storage reservoirs. Despite the interconnection of the system, its capacity to regularize inflows, and the increasing use of alternative sources, the country has faced several water and energy crises over the last years.

The energy trading market, structured in 2004, allows companies to define regulated and free contracts. Regulated contracts are defined in biddings of lowest price. In free contracts, the energy prices, amounts, and periods are freely negotiated. The positive or negative differences

\footnotetext{
* Corresponding author.

E-mail address: ihidalgo@unicamp.br (I.G. Hidalgo).
}

among the contracted, generated, and consumed energy are traded in the short-term market, wherein the Settlement Price of Differences (SPD) for energy is defined through mathematical models. For 2020, the SPD was limited between 39.68 and 559.75 R $\$$ MWh (CCEE, 2020a).

Porto (2016) analyzed SPD variations for recent years. In 2008 the SPD reached high values and in 2014 it achieved its maximum value. In both periods, the main reason for high SPD values was the absence of favorable hydrological conditions. Thus, the SPD that depends on hydrological conditions is a variable of risk associated with hydropower generation contracts. Alterations in the rainfall and temperature trends, as well as the occurrence of extreme events, complicate water resources management, increasing levels of uncertainty.

The impact of climate change on hydropower generation has been analyzed worldwide. In Africa, for example, can be cited SpaldingFecher et al. (2017), Lumbroso et al. (2015), and Harrison, Whittington, \& Wallace (2003). In America, Boehlert et al. (2016), Tarroja et al. (2016), Kopytkovskiy et al. (2015), Madani et al. (2014), and Haguma et al. (2014) investigated this topic. In Asian countries, the effects of future climate on hydroelectric generation were studied by Shrestha et al. (2016), Liu et al. (2016), Jahandideh-Tehrani et al. 
(2015), Park and Kim (2014), and Wang et al. (2014). In Europe, Sánchez and Izzo (2017), Lobanova et al. (2016), Gaudard et al. (2016), Timalsina et al. (2015), Sample et al. (2015), Gebre et al. (2014), Maran et al. (2014), and Gaudard et al. (2014) also explored this subject. In Oceania, the influence of climate variability in hydropower generation was examined, for example, in Caruso et al. (2017). Most of these studies deal with warmer temperatures and uncertainties about regional changes in the precipitation patterns.

In Brazil, Mohor et al. (2015), Schaeffer et al. (2013), and Soito and Freitas (2011) investigated the impact of climate change for hydropower generation in the Amazon region. The following references are also applied to Brazil and they are specifically related to the objects of this study. For this reason, they are described in details.

Silveira et al. (2014) carried out inflow projections for thirteen hydroelectric plants. They used six models from IPCC-AR4 for precipitations; A1B, A2, and B1 GHG emission scenarios; the Soil Moisture Account Procedure (SMAP) model for inflows; and the PenannMothiet method for evapotranspiration. The average annual inflow projected for 2010-2099 is compared with 1931-1999. For the Southeast, Center-west and South regions, the models show that the water inflows will likely decrease by $5 \%$ every 30 years. Regarding to the North and Northeast regions, the model outputs are divergent.

Silveira et al. (2016) analyzed the projections of precipitation and temperature for the São Francisco river basin utilizing 17 models of IPCC-AR5, with RCP 4.5 and RCP 8.5 scenarios, for 2011-2100. They employ 10-year moving averages, linear regression, and the MannKendall-Sen method. About $28 \%$ of the models did not adequately represent the variation in precipitation. All models presented positive trend for temperature. For the precipitation, regardless of divergence, the models show anomalies between $-20 \%$ and $20 \%$ every 30 -year period.

Tiezzi et al. (2014) simulated scenarios of climate change and evaluated their impact for five hydroelectric plants that belongs to the Southeast region. They utilize precipitation data from ETA CPTEC/HadCM3; A1B, A2, B1, and a fourth scenario of climate change, and the SMAPMEL model for inflows. The impact was analyzed through the product of the natural water inflow by the plant's average productivity. The results for 2011-2099 show an overall increase in water quantity, especially for the hydroelectric plants Furnas and Três Marias.

Schaeffer et al. (2018) investigated the potential vulnerabilities of the Brazilian energy sector for sixteen hydroelectric plants in the period 2071-2100. Climate projections were based on A2 and B2 GHG emissions scenarios from IPCC. According to the results, climate change may cause a drop from $8.6 \%$ to $10.8 \%$ in average annual inflow, with more intense impact (drop of 25\%) in the São Francisco basin.
As can be observed by the last four paragraphs, the studies related to the São Francisco river basin only evaluate the flow projections with no conclusions about the consequences for hydropower generation. Therefore, in this study we analyze the impact of climate variations for the operation of a hydroelectric plant called Três Marias, located in the upper São Francisco river basin, Brazil. The source of all data and the free tool employed are provided. As such, either this work can be replicated or its methodology can be applied to any other hydroelectric system.

It is also possible to realize that the studies diverge regarding the future climate in the region. For this reason, all scenarios predicted in the literature for the upper São Francisco basin are simulated. For each scenario, the water storage in the reservoir and energy produced by the plant are analyzed. The financial impact for extreme scenarios is presented. This way, the knowledge and the results obtained from this paper can help authorities, companies and researchers improve the management of the water and energy resources of the system.

The methodology adopted consists of four steps: (Section 0) hydrological model; (Section 0) hydropower model; (Section 0) future climate scenarios; and (Section 0) simulation of the hydrologicalhydropower model and evaluation of the results. Usually, the hydrological and hydropower systems are designed individually with more than one software and replicating data. This may compromise the decision-making process in terms of time and accuracy. In this paper we model both the hydrological and hydropower systems together, in a single free tool, sharing the same database.

\section{Upper São Francisco basin and Três Marias hydroelectric plant}

The São Francisco river basin has almost $640,000 \mathrm{~km}^{2}$ of drainage area and corresponds to $7.5 \%$ of the national territory. Its most important river, São Francisco, covers around $2700 \mathrm{~km}$, from the source to the mouth, passing by six Brazilian states (Fig. 1 - Left side). This basin is located between the Southeast and Northeast regions and occupies a significant part of the area recognized as being subject to critical periods of prolonged drought (Fig. 1 - Right side) (CBHSF, 2020).

The most important hydroelectric plants in this basin are Três Marias, Sobradinho, Itaparica, Paulo Afonso complex, and Xingó (Fig. 2). They represent almost $11 \%$ of the national installed capacity for hydropower generation. The first three plants (solid line) have reservoir with maximum volume of $19,528 \mathrm{hm}^{3} ; 34,117 \mathrm{hm}^{3}$; and 10,782 $\mathrm{hm}^{3}$, respectively. The last ones (dashed line) are run-of-river hydropower plants (ANA, 2020a; CEMIG, 2020c; CHESF, 2020).

Três Marias is the first plant of the cascade and the second largest reservoir of the basin. Upper São Francisco has an area of approximately
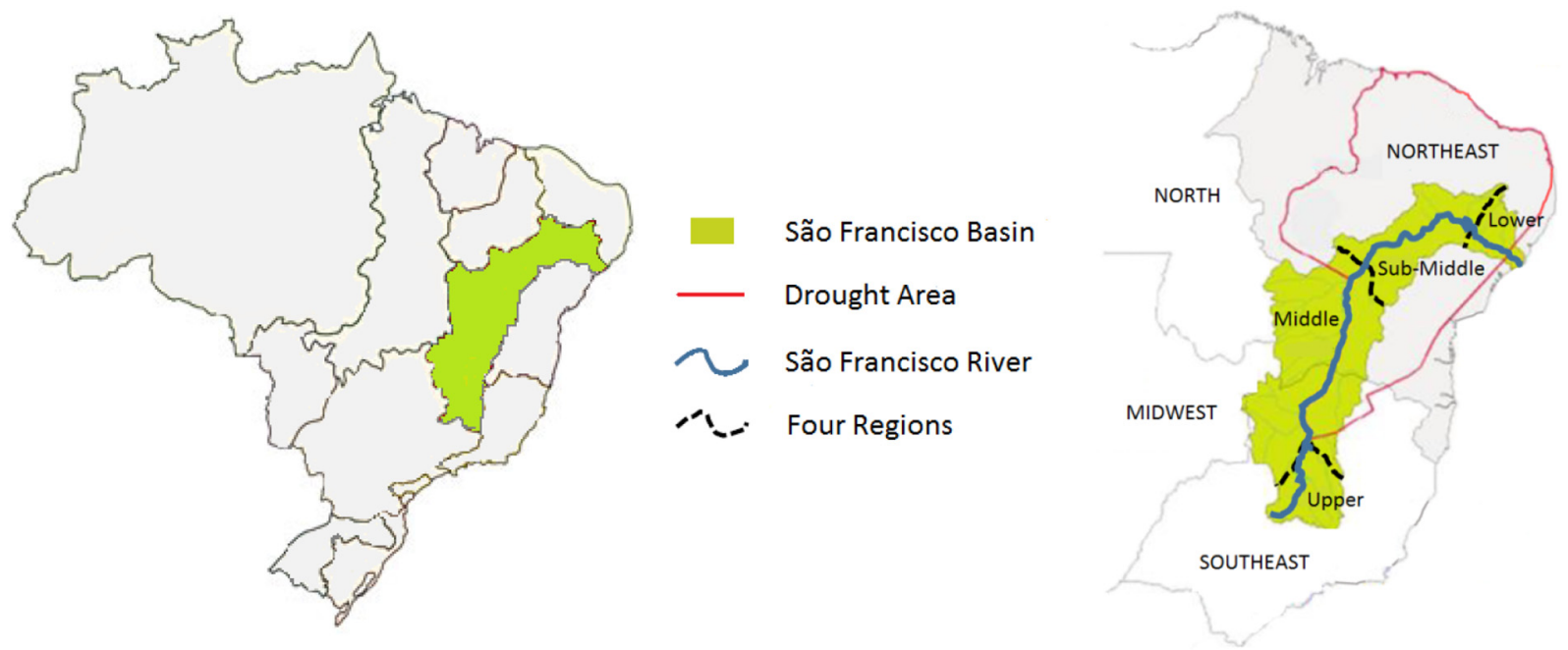

Fig. 1. Location of the São Francisco river basin in Brazil (Lerner, 2006 - adapted). 


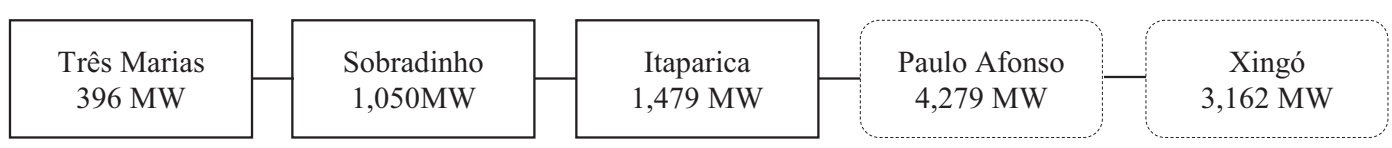

Source

Mouth

Fig. 2. Schematic diagram of the hydroelectric plants in the São Francisco river basin.

$51,000 \mathrm{~km}^{2}$. Therefore, the Três Marias hydroelectric plant at the upper São Francisco basin (Brazil) is the object of this study.

\section{Computational tool}

In order to assess the impact of changes in the rainfall and temperature patterns for the Três Marias hydroelectric plant, a hydrological-hydropower model is employed. Both parts (hydrological and hydropower) are designed, calibrated, validated, and simulated in the software RS Minerve.

RS Minerve is freely distributed to interested users and has been applied to studies in Switzerland, Spain, Peru, Brazil, France, and Nepal (Deval Castillo, Luengo García, Lorenzo Riera, García, \& de Paz García, 2011; García Hernández et al., 2013; Lujano Laura et al., 2016 and Tobin et al., 2011). For hydrological systems, RS Minerve offers seven models, identified as: SNOW-GSM, SWMM, GSM, SOCONT, HBV, GR4J, and SAC-SMA. For hydropower systems, it contains some objects that may represent a hydroelectric plant, such as: reservoir, penstock, turbine, and spillway. Details can be found in RS Minerve (2020).

\section{Methodology}

\section{Hydrological model}

The hydrological representation of the upper São Francisco basin is based on the HBV model. It is a semi-distributed conceptual model of rainfall-runoff transformation type (Bergstrom, 1992). As shown in Fig. 3, the hydrological model converts rainfall $(\mathrm{mm} / \mathrm{d})$ and potential evapotranspiration $(\mathrm{mm} / \mathrm{d})$ into water inflow $\left(\mathrm{m}^{3} / \mathrm{s}\right)$. Due to the size of the basin, the upper São Francisco is divided into 21 sub-basins in the hydrological model $\left(\mathrm{HBV}_{1}, \mathrm{HBV}_{2}, \ldots, \mathrm{HBV}_{21}\right)$. The choice of the sub-basins contemplates the stations in head water as much as possible for the broadest representation.

Rainfall data are provided by the National Water Agency through the Hidroweb software (ANA, 2020b). They are available for 49 measurement stations, in daily time-step, from 1987. Potential evapotranspiration data come from National Institute of Meteorology by BDMEP database (INMET, 2020). They are presented for 10 measurement stations, in monthly time-step, from 1961. The monthly data are converted to daily data, considering a constant evapotranspiration throughout the month. In order to evaluate the performance of the hydrological model the simulated water inflows are compared to the recorded water inflows. Recorded water inflow data are also provided by the National Water Agency through the Hidroweb software. They are available for the 21 measurement stations defined in the hydrological model.

HBV uses fifteen parameters, listed in Table 1 . The fifteen parameters of each sub-basin are calibrated, utilizing the Shuffled Complex Evolution - University of Arizona (SCE-UA) optimization algorithm. SCE-UA is a global optimization method based on several existing algorithms, including the genetic algorithm. SCE-UA introduces the concept of complex information exchange, named complex shuffling. RS Minerve (2020) presents a general description of the steps, a flow chart, an illustration, and the parameters of the SCE-UA algorithm.

The objective function (1) searches to maximize five indicators: Nash coefficient (Nash), Nash coefficient for logarithm values (Nashln), Pearson correlation coefficient (Pearson), Kling-Gupta efficiency (KGE), and bias score (BS) since their ideal value is equal to the maximum possible value and, at the same time, to minimize the value or the absolute value for three indicators: relative root mean square error (RRMSE), relative volume bias (RVB), and normalized peak error (NPE) since their ideal value corresponds to zero. Each indicator is weighted $\left(w_{1} \ldots w_{8}\right)$ with a value defined by the user. Details about the characteristics of the performance indicators can be found in RS Minerve (2020).

$$
\begin{gathered}
\operatorname{Max}\left({\text { Nash } . w_{1}}_{1}+\text { Nashln. }_{2}+\text { Pearson. } w_{3}+\text { KGE. } w_{4}+\text { BS. } w_{5}\right. \\
\left.- \text { RRMSE. } w_{6}-\mid \text { RVB. } w_{7}|-| N P E . w_{8} \mid\right)
\end{gathered}
$$

The 21 sub-basins presented good results for calibrating process followed by validation. As an example, Table 2 shows the performance indicator values at the end of the basin, i.e. near the Três Marias reservoir. For the first five indicators, the closer to " 1 " the better performance of the model. For the last three indicators, values near zero indicate a good performance.

Based on Table 2, it is possible to conclude, for example, that for high flows (indicator \#1) the calibration results are better than validation

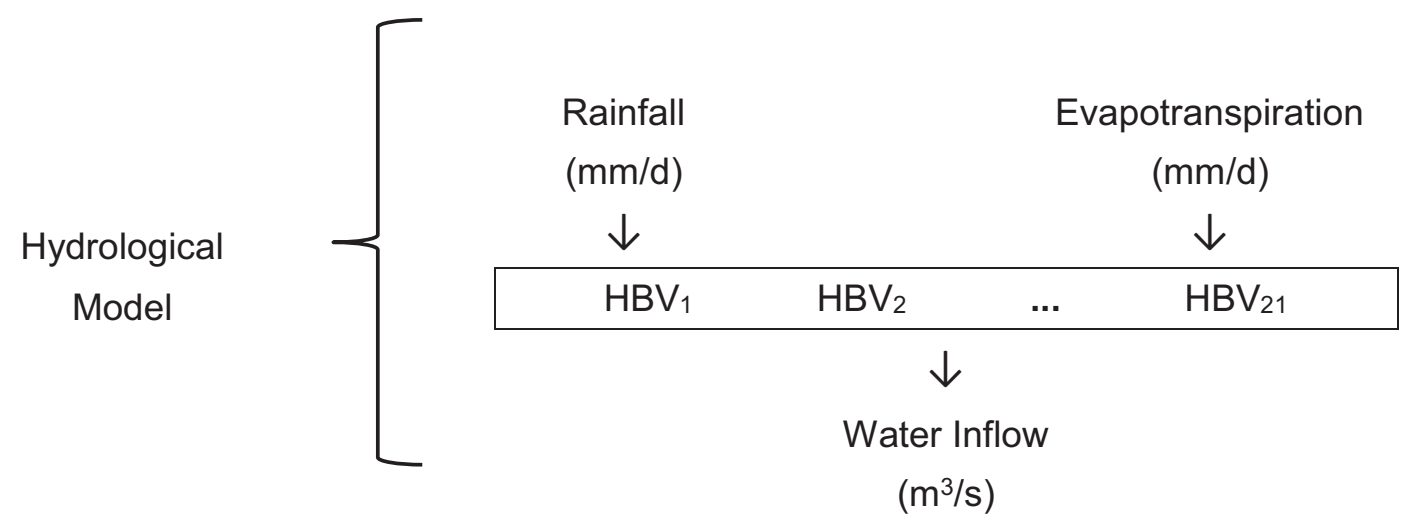

Fig. 3. Input-output variables of the hydrological model designed in RS Minerve. 
Table 1

Full list of parameters for the HBV model (RS Minerve, 2020).

\begin{tabular}{llll}
\hline Parameter & Unit & Description & Range \\
\hline A & $\mathrm{m}^{2}$ & Surface of the basin & $>0$ \\
CFMax & $\mathrm{mm} /{ }^{\circ} \mathrm{C} /$ day & Melting factor & 0.5 to 20 \\
CFR & - & Refreezing factor & 0.05 \\
CWH & - & Critical relative water content of the & 0.1 \\
& & Snow pack & 0 to 3 \\
TT & ${ }^{\circ} \mathrm{C}$ & Threshold temperature of rain/snow & 0 to 3 \\
TTInt & ${ }^{\circ} \mathrm{C}$ & Temperature interval for rain/snow & \\
& & mixing & 0 \\
TTSM & ${ }^{\circ} \mathrm{C}$ & Threshold temperature for snow melt & 0 \\
Beta & - & Model parameter (shape coefficient) & 1 to 5 \\
FC & $\mathrm{m}$ & Maximum soil storage capacity & 0.050 to 0.65 \\
PWP & - & Soil permanent wilting point threshold & 0.030 to 1 \\
SUMax & $\mathrm{m}$ & Upper reservoir water level threshold & 0 to 0.10 \\
Kr & $1 / \mathrm{d}$ & Near surface flow storage coefficient & 0.05 to 0.5 \\
Ku & $1 / \mathrm{d}$ & Interflow storage coefficient & 0.01 to 0.4 \\
Kl & $1 / \mathrm{d}$ & Baseflow storage coefficient & 0 to 0.15 \\
Kperc & $1 / \mathrm{d}$ & Percolation storage coefficient & 0 to 0.8 \\
\hline & & &
\end{tabular}

Table 2

Performance indicators after calibrating and validating processes for Três Marias reservoir.

\begin{tabular}{lllc}
\hline$\#$ & Indicator & Calibration value & Validation value \\
\hline 1 & Nash & 0.87287 & 0.86059 \\
2 & Nash-ln & 0.89635 & 0.91432 \\
3 & Pearson & 0.93892 & 0.94168 \\
4 & Kling-Gupta & 0.89645 & 0.81704 \\
5 & Bias score & 0.99579 & 0.96647 \\
6 & RRMSE & 0.37422 & 0.36417 \\
7 & Relative volume bias & 0.06491 & -0.15478 \\
8 & Normalized peak error & 0.00409 & -0.10243 \\
\hline
\end{tabular}

results, whereas for low flows (indicator \#2) the opposite occurs. Additionally, the simulated discharge as well as the simulated peak discharge (indicators \#7 and \#8) is, on average, above the recorded information for the calibration results (positive values) and below it for the validation results (negative values).

\section{Hydropower model}

The hydropower model is based on the production function, Eq. (2). The goal of the production function is to quantify the power generation of a hydroelectric plant, considering the efficiency of the turbinegenerator sets, net head, and water discharge.

$p=k \cdot \eta_{t} \cdot \eta_{g} \cdot\left[h_{f b}(x)-h_{t r}(u)-h_{p l}\right] \cdot q$

where:

$p$ Is the instantaneous power obtained in the conversion process of the hydraulic potential energy to electrical energy (MW).

$k$ Is the gravity constant, multiplied by the water specific weight and divided by $10^{6}$. Its value is $0.00981\left(\mathrm{MW} /\left(\mathrm{m}^{3} / \mathrm{s}\right) / \mathrm{m}\right)$.

$\eta_{t} . \eta_{g}$ Is the efficiency of the turbine-generator set in the conversion process of the mechanical energy to electrical energy.

$x$ Is the water storage in the reservoir of the plant $\left(\mathrm{hm}^{3}\right)$.

$h_{f b}(x)$ Is the forebay elevation which is a function of the water storage $x(\mathrm{~m})$.

$u$ Is the total water release of the plant, that is, the sum of the water discharge and the water spillage $\left(\mathrm{m}^{3} / \mathrm{s}\right)$.

$h_{t r}(u)$ Is the tailrace elevation which is a function of the water release $u(\mathrm{~m})$.

$h_{p l}$ Is the penstock head loss which is a function of the water discharge ( $\mathrm{m})$.

$q$ Is the water discharge by the turbines in the powerhouse $\left(\mathrm{m}^{3} / \mathrm{s}\right)$.

As shown in Fig. 4, from the water inflow (output of the hydrological model), plus the reservoir initial level $(\mathrm{m})$ and water discharge values $\left(\mathrm{m}^{3} / \mathrm{s}\right)$, the hydropower model computes the power generation (MW) and storage volume $\left(\mathrm{hm}^{3}\right)$.

The operation data related with the hydropower model are provided by the energy company responsible for the power generation in Três Marias, also in daily time-step, for the last 20 years (CEMIG, 2020a). The functions that describe the plant's physical characteristics come from the Electric Energy Trading Chamber. They are available in the official file named Hidr.dat (CCEE, 2020b).

The calibration and validation processes of the hydropower model consists of adjusting the functions that describe the plant's physical characteristics. As shown in Hidalgo et al. (2010), the quality of these functions significantly impacts the result of computational models used for planning the power system, contributing to bring the real and simulated operation closer.

The hydropower model utilizes four functions that describe the plant's physical characteristics. For the reservoir, the level-volume polynomial is employed. Regarding penstocks (that carry water from the reservoir towards the generation units), their length, diameter, roughness, and kinematic viscosity are necessary. For the turbine-generator sets, the threshold in the level of the reservoir to start and stop them are considered, as well as the discharge-performance relation.

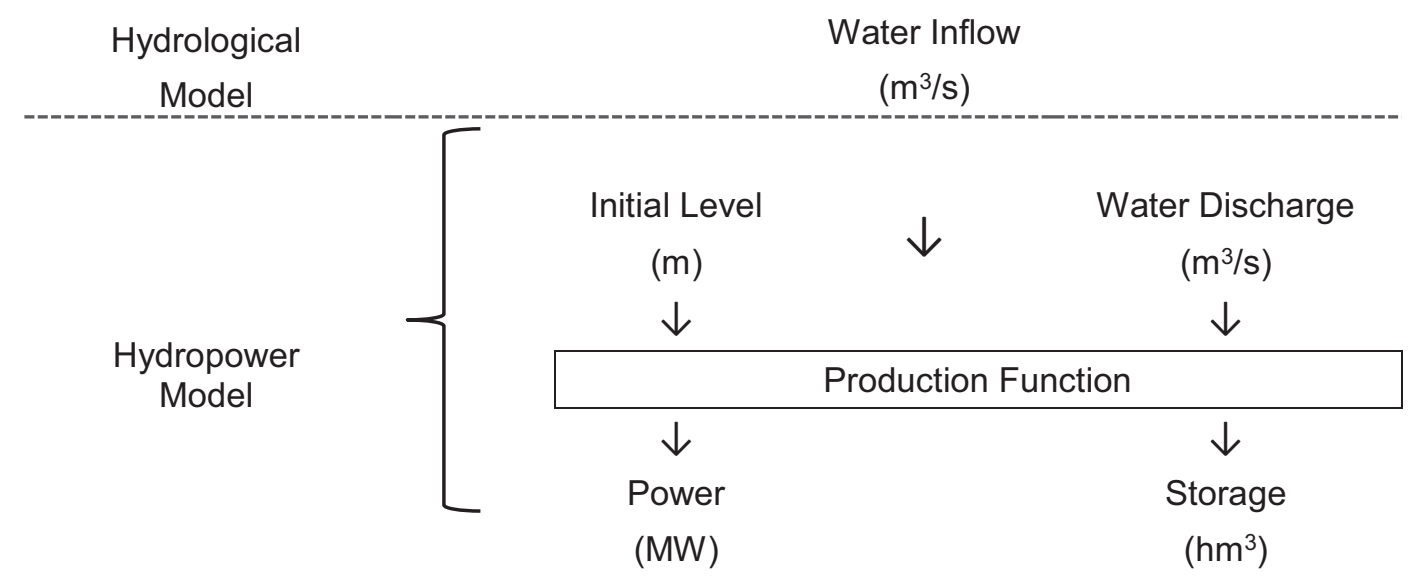

Fig. 4. Input-output variables of the hydropower model designed in RS Minerve. 
Table 3

MAPE, MPE, and RRMSE between simulated and recorded operation for the Três Marias hydroelectric plant.

\begin{tabular}{llrrl}
\hline$\#$ & Variable & MAPE & MPE & RRMSE \\
\hline 1 & Forebay level & 0.30 & -0.30 & 0.00 \\
2 & Water inflow & 21.28 & -1.61 & 0.40 \\
3 & Water discharge & 0.00 & 0.00 & 0.00 \\
4 & Power generation & 2.84 & -2.30 & 0.03 \\
\hline
\end{tabular}

The adjusting of these functions is done using historic data of the last 20 years. Table 3 shows the mean absolute percentage error (MAPE), mean percentage error (MPE), and relative root mean square error (RRMSE) of the main variables related to the hydropower model.

Based on Table 3, it is possible to realize that the greatest difference between the simulated and recorded operation is for water inflow (column: MAPE - line: 2). This difference is negative (column: MPE - line: 2 ), i.e. simulated water inflows are, on average, lower than the recorded information. That is coherent with indicators 7 and 8 of Table 2. For this reason, although the water discharge is fulfilled (line 3), the forebay level decreases over the time (column: MPE - line: 1). As consequence, the gross head decreases and the simulated power generation is also lower than the recorded information (column: MPE - line: 4). The RRMSE column confirms these observations.

\section{Future climate scenarios}

The scenarios contemplate the predictions of climate change published in Silveira et al. (2014, 2016), Tiezzi et al. (2014), and Schaeffer et al. (2018) for the upper São Francisco; described in the Introduction section. They cover the rainfall and temperature variations, between the minimum and maximum extremes, and the possible displacements of the dry and rainy seasons throughout the year. Therefore, the scenarios consider alterations in the rainfall and temperature patterns both in quantitative and seasonal terms.

For rainfall, the predictions are divergent regarding the decrease or increase of this variable. The scenarios range from $-20 \%$ to $+20 \%$ under a time-step of $10 \%$. Therefore, $-20 \%,-10 \%,+10 \%$, and $+20 \%$ are the variations of rainfall analyzed in this study.

The predictions for temperature indicate a rise of up to $7^{\circ} \mathrm{C}$. Evapotranspiration values for $1{ }^{\circ} \mathrm{C}, 2^{\circ} \mathrm{C}, 3^{\circ} \mathrm{C}, 5^{\circ} \mathrm{C}$, and $7{ }^{\circ} \mathrm{C}$ are calculated by the Thornthwaite method (Thornthwaite, 1948) because it showed the best fit for the historical data. The results obtained show an increase in the evapotranspiration rate of $7 \%, 16 \%, 28 \%, 59 \%$, and $107 \%$; respectively. These values are consistent with the results presented in Kosa (2009).

The possible changes in quantitative and seasonal terms for the dry and rainy seasons in the upper São Francisco are presented by Tiezzi et al. (2014) in Graphic 1D. According to this reference, there is no temporal change for the dry season. However, the rainy season may start one month in advance, i.e. in August instead of September.
Additionally, this reference indicates rainfall events more intense in the first and last four months of the year. Therefore, for this scenario, the rainfall values are increased by $20 \%, 15 \%, 10 \%$, and $5 \%$ in the months 01 and 12,02 and 11,03 and 10,04 and 09; respectively.

Two values for reservoir initial level are employed in the scenarios. The first one, $565.00 \mathrm{~m}$, corresponds to the approximate average level of the last 20 years in Três Marias reservoir. The second one, $558.31 \mathrm{~m}$, refers to the initial level of the reservoir for the sequence of water discharges employed in the scenarios.

Therefore, as shown in Table 4, for covering the predictions of climate change extracted from the literature a combination of four scenarios for rainfall $(+10 \%,+20 \%,-10 \%$, and $-20 \%)$, six for evapotranspiration $(0 \%, 7 \%, 16 \%, 28 \%, 59 \%$, and $107 \%)$, and two for reservoir initial level ( $565.00 \mathrm{~m}$ and $558.31 \mathrm{~m}$ ) is evaluated for a one-year period. These 48 scenarios are divided in wet $(1 \ldots 24)$ and dry $(25 \ldots 48)$ scenarios. Moreover, four shifted scenarios are analyzed (49...52). The scenarios 49 and 50 refer to the early rainy season (in August instead of September). The scenarios 51 and 52 also consider early rainy season, but add an increase of $20 \%, 15 \%, 10 \%$, and $5 \%$ in the rainfall values for the first and last four months of the year. Again, both options of reservoir initial level are taken into account. In total, 52 scenarios are analyzed.

Simulation of the hydrological-hydropower model and evaluation of the results

The results of the simulated scenarios are presented in three parts: (Section 0) wet scenarios, (Section 0) dry scenarios, and (Section 0) shifted scenarios. The simulated scenarios with climate change are compared to the recorded scenarios without climate variation. For each simulated scenario, at least two questions are examined:

(1) Does the reservoir level (output variable) reach the minimum or maximum limit of $549.20 \mathrm{~m}$ or $572.50 \mathrm{~m}$, respectively, any time during the simulation? If the reservoir level goes down the minimum, water discharge values (input variable) are likely not fulfilled. Otherwise, if it exceeds the maximum limit, a certain amount of water needs to be spilled.

(2) Does the simulated scenario show results with gain or loss in the power generation (output variable) in relation to the recorded scenario? According to Eq. (2), the forebay level, $h_{f b}$ $(x)$, impacts the power generation, $p$. Therefore, the reservoir final level and total produced energy are the most important variables for the results analysis.

\section{Wet scenarios}

The maximum limit of the reservoir was reached but not exceeded by the wetter scenario (rainfall $=+20 \%$, ETP $=0 \%$, and reservoir initial level $=565.00 \mathrm{~m}$ ). Therefore, it was not necessary to spill water.

Table 4

Characteristics of the 52 analyzed scenarios.

\begin{tabular}{|c|c|c|c|c|}
\hline \multicolumn{2}{|c|}{ Scenario } & \multirow[t]{2}{*}{ Rainfall } & \multirow[t]{2}{*}{ Evapotranspiration (ETP) } & \multirow[t]{2}{*}{ Reservoir initial level } \\
\hline \# & Name & & & \\
\hline $1 \ldots 24$ & Wet & $+10 \%,+20 \%$ & $0 \%, 7 \%, 16 \%, 28 \%, 59 \%, 107 \%$ & $565.00 \mathrm{~m} 558.31 \mathrm{~m}$ \\
\hline $25 \ldots 48$ & Dry & $-10 \%,-20 \%$ & & \\
\hline $49 \ldots 50$ & Shifted & Month $08=09$ & (No change) & \\
\hline \multirow[t]{5}{*}{$51 \ldots 52$} & Shifted & Month $08=09$ & & \\
\hline & & 01 and $12=+20 \%$ & & \\
\hline & & 02 and $11=+15 \%$ & & \\
\hline & & 03 and $10=+10 \%$ & & \\
\hline & & 04 and $09=+05 \%$ & & \\
\hline
\end{tabular}


Table 5

Results for wet scenarios.

\begin{tabular}{|c|c|c|c|c|c|c|c|}
\hline \multicolumn{2}{|c|}{ Scenario } & \multirow{2}{*}{$\begin{array}{l}\Delta \text { Final } \\
\text { Level }(\mathrm{m})\end{array}$} & \multirow{2}{*}{$\begin{array}{l}\Delta \text { Energy } \\
(\mathrm{MWh})\end{array}$} & \multicolumn{2}{|c|}{ Scenario } & \multirow{2}{*}{$\begin{array}{l}\Delta \text { Final } \\
\text { level }(\mathrm{m})\end{array}$} & \multirow{2}{*}{$\begin{array}{l}\Delta \text { Energy } \\
\text { (MWh) }\end{array}$} \\
\hline Rainfall & ETP & & & Rainfall & ETP & & \\
\hline \multicolumn{8}{|c|}{ Reservoir initial level $=565.00 \mathrm{~m}$} \\
\hline \multirow[t]{6}{*}{$+10 \%$} & $0 \%$ & 3.38 & $76,058.64$ & \multirow[t]{6}{*}{$+20 \%$} & $0 \%$ & 6.89 & $153,198.96$ \\
\hline & $7 \%$ & 2.54 & $59,270.64$ & & $7 \%$ & 5.90 & $135,646.56$ \\
\hline & $16 \%$ & 1.56 & $38,435.76$ & & $16 \%$ & 4.79 & $113,714.16$ \\
\hline & $28 \%$ & 0.34 & $11,800.56$ & & $28 \%$ & 3.45 & $85,565.28$ \\
\hline & $59 \%$ & -3.80 & $-57,902.64$ & & $59 \%$ & 0.39 & $17,845.44$ \\
\hline & $107 \%$ & -8.52 & $-152,060.88$ & & $107 \%$ & -5.12 & $-79,440.48$ \\
\hline \multicolumn{8}{|c|}{ Reservoir initial level $=558.31 \mathrm{~m}$} \\
\hline \multirow[t]{6}{*}{$+10 \%$} & $0 \%$ & 4.97 & $103,071.36$ & \multirow[t]{6}{*}{$+20 \%$} & $0 \%$ & 9.96 & $201,835.20$ \\
\hline & $7 \%$ & 3.69 & $80,442.72$ & & $7 \%$ & 8.84 & $180,474.96$ \\
\hline & $16 \%$ & 2.18 & $52,074.24$ & & $16 \%$ & 7.14 & $152,098.08$ \\
\hline & $28 \%$ & 0.34 & $15,416.88$ & & $28 \%$ & 5.07 & $115,003.92$ \\
\hline & $59 \%$ & \multirow{2}{*}{\multicolumn{2}{|c|}{ Below minimum }} & & $59 \%$ & 0.39 & $23,039.76$ \\
\hline & $107 \%$ & & & & $107 \%$ & \multicolumn{2}{|c|}{ Below minimum } \\
\hline
\end{tabular}

Table 5 shows the results for the 24 wet scenarios. For each scenario, the variation of the reservoir final level ( $\Delta$ Final Level) and total produced energy ( $\Delta$ Energy) of the simulated scenario in relation to the recorded one is presented. The reservoir level went down below the minimum limit for the three less wet scenarios, identified in Table 5 with the text "below minimum". For these three scenarios, the water discharge values were not accomplished.

As the evapotranspiration rate increases the reservoir level, and consequently the power production, decreases. Of the 24 scenarios, 18 present positive values for the output variables, 3 display negative results, and 3 cannot meet the water discharge values. The two most optimistic scenarios (rainfall $=+20 \%$, ETP $=0 \%$, and both reservoir initial levels) show, on average, $\Delta$ Final Level $=8.42 \mathrm{~m}$ and $\Delta$ Energy $=177,517.08 \mathrm{MWh}$.

\section{Dry scenarios}

For all dry scenarios the reservoir level stayed below the maximum limit. This was expected, since in the wet scenarios it was only reached once.

Table 6 shows the results for the 24 dry scenarios. The reservoir level decreased below $549.20 \mathrm{~m}$ (minimum limit) in the three dryer scenarios with reservoir initial level equal to $565.00 \mathrm{~m}$ and in all scenarios performed with initial level of $558.31 \mathrm{~m}$. In these scenarios, there was not enough water in the reservoir to meet the water discharge goals. They are identified in Table 6 with the text "below minimum".

There are no positive results in the dry scenarios. Negative values are presented by 9 scenarios. For all the other 15 scenarios the reservoir level decreased below the minimum limit. The less pessimistic scenario

Table 6

Results for dry scenarios.

\begin{tabular}{|c|c|c|c|c|c|c|c|}
\hline \multicolumn{2}{|c|}{ Scenario } & \multirow{2}{*}{$\begin{array}{l}\Delta \text { Final } \\
\text { level }(\mathrm{m})\end{array}$} & \multirow{2}{*}{$\begin{array}{l}\Delta \text { Energy } \\
\text { (MWh) }\end{array}$} & \multicolumn{2}{|c|}{ Scenario } & \multirow{2}{*}{$\begin{array}{l}\Delta \text { Final } \\
\text { level }(\mathrm{m})\end{array}$} & \multirow{2}{*}{$\begin{array}{l}\Delta \text { Energy } \\
\text { (MWh) }\end{array}$} \\
\hline Rainfall & ETP & & & Rainfall & ETP & & \\
\hline \multicolumn{8}{|c|}{ Reservoir initial level $=565.00 \mathrm{~m}$} \\
\hline \multirow[t]{6}{*}{$-10 \%$} & $0 \%$ & -4.59 & $-83,091.36$ & $-20 \%$ & $0 \%$ & -8.76 & $-167,760.00$ \\
\hline & $7 \%$ & -5.54 & $-100,280.16$ & & $7 \%$ & -9.56 & $-183,477.60$ \\
\hline & $16 \%$ & -6.67 & $-121,563.60$ & & $16 \%$ & -10.50 & $-202,830.96$ \\
\hline & $28 \%$ & -8.06 & $-148,632.48$ & & $28 \%$ & \multirow{3}{*}{\multicolumn{2}{|c|}{ Below minimum }} \\
\hline & $59 \%$ & -11.07 & $-211,552.80$ & & $59 \%$ & & \\
\hline & $107 \%$ & -11.29 & $-278,410.32$ & & $107 \%$ & & \\
\hline \multicolumn{8}{|c|}{ Reservoir initial level $=558.31 \mathrm{~m}$} \\
\hline \multirow[t]{6}{*}{$-10 \%$} & $0 \%$ & \multirow{6}{*}{\multicolumn{2}{|c|}{ Below minimum }} & \multirow[t]{6}{*}{$-20 \%$} & $0 \%$ & \multirow{6}{*}{\multicolumn{2}{|c|}{ Below minimum }} \\
\hline & $7 \%$ & & & & $7 \%$ & & \\
\hline & $16 \%$ & & & & $16 \%$ & & \\
\hline & $28 \%$ & & & & $28 \%$ & & \\
\hline & $59 \%$ & & & & $59 \%$ & & \\
\hline & $107 \%$ & & & & $107 \%$ & & \\
\hline
\end{tabular}

Table 7

Results for shifted scenarios.

\begin{tabular}{|c|c|c|c|c|c|}
\hline \multirow{2}{*}{$\frac{\text { Scenario }}{\text { Rainfall }}$} & \multirow{2}{*}{$\begin{array}{l}\Delta \text { Final } \\
\text { level }(\mathrm{m})\end{array}$} & \multirow{2}{*}{$\begin{array}{l}\Delta \text { Energy } \\
\text { (MWh) }\end{array}$} & \multirow{2}{*}{$\frac{\text { Scenario }}{\text { Rainfall }}$} & \multirow{2}{*}{$\begin{array}{l}\Delta \text { Final } \\
\text { level }(\mathrm{m})\end{array}$} & \multirow{2}{*}{$\begin{array}{l}\Delta \text { Energy } \\
\text { (MWh) }\end{array}$} \\
\hline & & & & & \\
\hline \multicolumn{6}{|c|}{ Reservoir initial level $=565.00 \mathrm{~m}$} \\
\hline $\begin{array}{l}\text { Month } \\
08=09\end{array}$ & 0.31 & 1984.08 & $\begin{array}{l}\text { Month } \\
08=09 \\
01 \text { and } 12=+20 \% \\
02 \text { and } 11=+15 \% \\
03 \text { and } 10=+10 \% \\
04 \text { and } 09=+05 \%\end{array}$ & 5.93 & $133,921.44$ \\
\hline \multicolumn{6}{|c|}{ Reservoir initial level $=558.31 \mathrm{~m}$} \\
\hline $\begin{array}{l}\text { Month } \\
08=09\end{array}$ & 0.31 & 2864.64 & $\begin{array}{l}\text { Month } \\
08=09 \\
01 \text { and } 12=+20 \% \\
02 \text { and } 11=+15 \% \\
03 \text { and } 10=+10 \% \\
04 \text { and } 09=+05 \%\end{array}$ & 8.88 & $178,346.16$ \\
\hline
\end{tabular}

( rainfall $=-10 \%$, ETP $=0 \%$, and reservoir initial level $=565.00 \mathrm{~m}$ ) presents $\Delta$ Final Level $=-4.59 \mathrm{~m}$ and $\Delta$ Energy $=-83,091.36 \mathrm{MWh}$.

\section{Shifted scenarios}

As well as wet scenarios, shifted scenarios refer to a rise in rainfall amount. The maximum limit of the reservoir was reached, but again not overpassed, by the scenario with addition in rainfall values and reservoir initial level equal to $565.00 \mathrm{~m}$.

There was no simulated scenario with a reservoir level below the minimum limit. Therefore, the water discharge values were fulfilled in all scenarios.

The results from shifted scenarios are in Table 7. As expected, since these scenarios correspond to a rise in rainfall without increasing temperature/evapotranspiration, all output variables are positive. The two scenarios with early rainy season (first three columns of Table 7) do not show significant changes since the rainfall of September reproduced in August was not intense. The other two scenarios (last three columns of Table 7) present, on average, $\Delta$ Final Level $=7.40 \mathrm{~m}$ and $\Delta$ Energy $=156,133.80 \mathrm{MWh}$.

\section{Discussion}

Seeing the wet and dry scenarios, it is possible to realize that negative outputs from studies with higher water level correspond to studies with lower water level that cannot meet the water discharge values. In other words, negative results from scenarios with reservoir initial level equal to $565.00 \mathrm{~m}$ are converted to "below minimum" in scenarios with reservoir initial level equal to $558.31 \mathrm{~m}$. That happens because there is not enough water in the reservoir to accomplish the water discharge values.

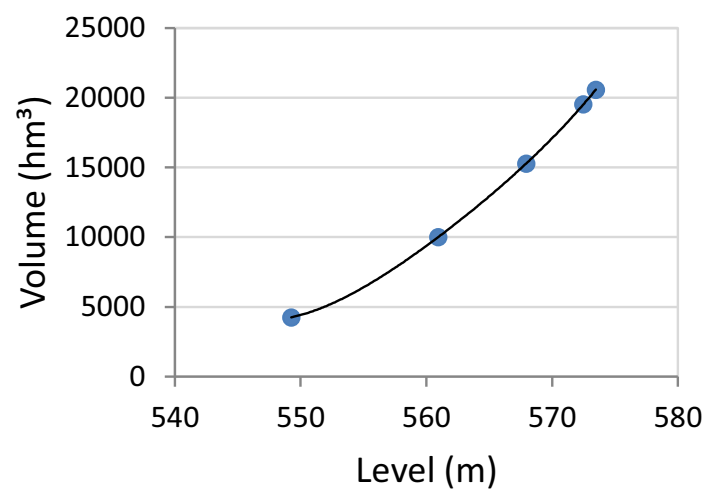

Fig. 5. Level-volume polynomial of the Três Marias reservoir (CCEE, 2020b). 


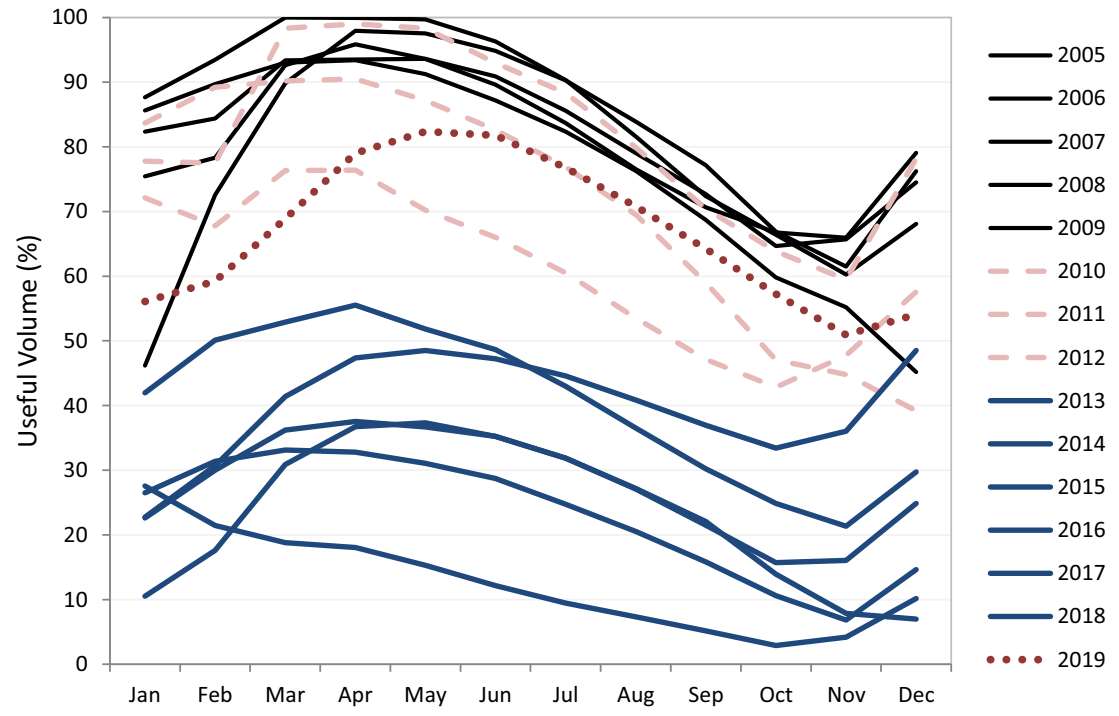

Fig. 6. Useful volume in the Três Marias reservoir over the last 15 years (CEMIG, 2020a, 2020b).

Examining wet and shifted scenarios, it can be concluded that the gains related to the output variables are more expressive in scenarios with lower reservoir initial level. That can be justified with the exponential function that relates level and volume of the reservoir (Fig.5). The lower the reservoir water level, the greater the impact of rising rainfall because the reservoir level increases faster, as well as the gross head, and consequently the power generation, Eq. (2).

Fig. 6 shows the percentage of useful volume in the Três Marias reservoir over the last 15 years. As can be seen, the reservoir water level remained much higher from 2005 to 2009 than from 2013 to 2018. The average percentage of useful volume in $2005-2009$ was $80.79 \%$, in $2010-2012$ reduced to $71.73 \%$, in $2013-2018$ dropped off $27.88 \%$, and in 2019 increased to $66.79 \%$. Therefore, both scenarios, with reservoir initial level equal to $558.31 \mathrm{~m}$ ( $27.26 \%$ of useful volume) and equal to $565.00 \mathrm{~m}$ ( $56.59 \%$ of the useful volume) are close to the reality of the recent years.

The extremes of generation can be extracted from the wettest and driest scenarios. For the wettest scenario, that means, with more resource (rainfall $=+20 \%$, ETP $=0 \%$, and reservoir initial level $=565.00 \mathrm{~m}$ ) the maximum limit of the reservoir was reached. Therefore, it was possible to obtain the plant's maximum power of $396 \mathrm{MW}$. For the driest scenario, that means, with less resource (rainfall $=-20 \%$, ETP $=107 \%$, and reservoir initial level $=558.31 \mathrm{~m}$ ) the minimum limit of the reservoir was not reached. Consequently, it was not possible to produce energy.

The variability of generation can be analyzed from the scenarios with the highest and lowest results. For the scenario with the highest result ( rainfall $=+20 \%$, ETP $=0 \%$, and reservoir initial level $=558.31 \mathrm{~m}$ ) an extra energy of 201,835.20 MWh was produced throughout the year. For the scenario with the lowest result (rainfall $=-10 \%$ ETP $=107 \%$,

Table 8

Scenarios A, B, C, and D.

\begin{tabular}{llllll}
\hline Scenario & Change & Rainfall & $\begin{array}{l}\text { Reservoir } \\
\text { Level }(\mathrm{m})\end{array}$ & $\begin{array}{l}\Delta \text { Final level } \\
(\mathrm{m})\end{array}$ & $\begin{array}{l}\Delta \text { Energy } \\
(\mathrm{MWh})\end{array}$ \\
\hline A & Uniform & $+10 \%$ & 565.00 & 3.38 & $76,058.64$ \\
B & & 558.31 & 4.97 & $103,071.36$ \\
C & Varied & Month & 565.00 & 5.93 & $133,921.44$ \\
D & & $08=09$ & 558.31 & 8.88 & $178,346.16$ \\
& & 01 and 12 $=+20 \%$ & & & \\
& 02 and $11=+15 \%$ & & \\
& 03 and $10=+10 \%$ & & \\
& 04 and 09 $=+05 \%$ & & \\
\hline
\end{tabular}

and reservoir initial level $=565.00 \mathrm{~m}$ ) a reduction of 278,410.32 MWh was observed.

In order to compare average or uniform and instantaneous extreme impacts of climate change on the reservoir of interest, four scenarios are analyzed. For average or uniform impacts, two scenarios are extracted from Table 5. For instantaneous extreme impacts, two scenarios are extracted from Table 7. The considered scenarios and their results are shown in Table 8. These four scenarios (named A, B, C, and D) are similar because all of them have an extra rainfall of $10 \%$, on monthly average, without increasing temperature/evapotranspiration.

Comparing A with $\mathrm{C}$ and $\mathrm{B}$ with $\mathrm{D}$ (same reservoir initial level), it is possible to realize that scenarios with varied changes ( $C$ and $D$ ) produce more energy than scenarios with uniform changes (A and B). Scenario C produces $76 \%$ more energy than scenario $A$; whereas scenario $D$ produces $73 \%$ more energy than scenario B. Therefore, scenarios with varied changes differ from scenarios with uniform changes significantly.

For the scenario with greatest results (rainfall $=+20 \%$, ETP $=0 \%$, and reservoir initial level $=558.31 \mathrm{~m}$ ) the storage final level increases $9.96 \mathrm{~m}$ and an extra energy of 201,835.20 MWh is produced throughout the year. The energy price in the short-term market (SPD), defined for 2020 , is up to $559,75 \mathrm{R} \$ / \mathrm{MWh}$ (price ceiling). Therefore, this scenario may bring an annual monetary gain of $\mathrm{R} \$ 112,977,253.20$ or US\$ $22,595,450.64$ ( 1 US\$ = $5 \mathrm{R} \$$ ).

For the scenario with lowest results (rainfall $=-10 \%$, ETP $=107 \%$, and reservoir initial level $=565.00 \mathrm{~m}$ ) the storage final level decreases $11.29 \mathrm{~m}$, with reduction of $278,410.32 \mathrm{MWh}$ and possibility of monetary loss up to $\mathrm{R} \$ 155,840,176.62$ or US\$ $31,168,035.32$.

The object of this study, Três Marias, was the first hydraulic enterprise in the country with multiple purposes. In addition to generating energy, the reservoir is used to control the flow of the river (allowing navigation and preventing flooding), irrigation, tourism, and leisure. The total installed capacity of Três Marias hydroelectric plant, 396 MW, is sufficient to supply 1.1 million people. In this context, discussions on the impacts of climate change become even more relevant.

Climatic change can cause alterations in the: (I) average value of precipitation, (II) geographic distribution of rain, and (III) seasonal patterns of rainfall. In addition, climate change can also bring an increase in average temperatures. Items (I) and (II) were especially evaluated in scenarios 1 to 48. Item (III) was analyzed in scenarios 49 to 52. The alterations affect the sectors of power generation, transmission, and distribution, as well as the behavior of final consumers.

For the generation sector, the impact is due to hydrological risk. Climatic change modifies the amount of water that reaches the reservoirs, 
which may cause a reduction in the power generation capacity. To mitigate this problem it is possible to expand the generation capacity from alternative renewable sources (non-hydro); promote energy efficiency programs; adhere to the power reallocation mechanism (transferring power from plants with higher water inflow to plants with lower water inflow); and invest in hybrid generation systems that combine the benefits, for example, of hydro generation with solar or wind generation.

The transmission sector can be affected by the unavailability of power transmission lines. The increase in temperature, associated with prolonged drought conditions, maximizes the risk of fires that can reach the transmission lines. To mitigate this risk, flameproof paint can be applied to wooden posts in risk locations. In addition, inspections and cleaning of the vegetation that interferes in the transmission lines should be continuously carried out.

In the distribution sector, the occurrence of intense rainfalls accompanied by windstorms and lightning can cause physical damage to installations that transport energy to final consumers. As a consequence, company costs increase due to reimbursement to consumers for interruptions in the supply of energy. To reduce the magnitude of this risk, preventive measures can be adopted, such as the management of urban trees by pruning and the forecasting of storms through the operation of weather stations and radars.

Regarding to the behavior of final consumers, high temperatures can cause an increase in electricity consumption and an overload of the electricity distribution system. This risk can be managed by monitoring operating conditions and prioritizing expansion works. According to CEMIG (2020d), if the scenario of emissions A1B of the IPCC for 2010-2100 is confirmed, based on climatological simulations and calculation of physical guarantees, there may be a reduction in the availability of hydropower generation in Brazil from 15\% to $25 \%$.

\section{Conclusions}

In this paper, a hydrological-hydropower model is designed to simulate the impact of future climate scenarios for hydropower generation. The HBV conceptual model and SCE-UA optimization algorithm, embedded in RS Minerve, as well as the hydroelectric production function and Thornthwaite method are employed. In total, 52 scenarios of climate change are analyzed.

The simulated scenarios with climate alterations are compared to the recorded scenarios without changing in the rainfall and temperature patterns. Both of them are carried out in the same hydrological-hydropower model. Therefore, the results show the impact of climate change with no interference of the model performance.

The predicted wet scenarios do not seem to be a problem for the plant because, even for the extreme positive values of rainfall, the reservoir level did not exceed the maximum limit during the simulation. The scenarios with shifted and concentrated rainfall are also non-issues for the reservoir maximum limit. It is worth noting that Três Marias reservoir is the second largest of the basin.

The predicted dry scenarios show simulation results that compromise the operation of Três Marias. For $37.50 \%$ of these scenarios there is loss in the amount of water storage and produced energy. For the remaining $62.50 \%$, the simulated operation cannot meet the water discharge values. That is concerning because, since Três Marias is the first plant in the cascade, sometimes it works with discharge restrictions due to drought in the downstream reservoir. Additionally, about $80 \%$ of the waters at São Francisco river come from the upper part of the basin. Therefore, this is an important area for the whole basin, considered a strategic reserve for the basin water security.

Lastly the hydrological and hydropower models were designed together in a single free tool. That makes the model easier to be replicated for anyone. The source of all data and the free tool employed are provided. As such, either this work can be replicated or its methodology can be applied to any other hydroelectric system. The knowledge and the results obtained from this paper can help authorities, companies and researchers improve the management of the water and energy resources of a system.

\section{Declaration of competing interest}

The authors declare that they have no known competing financial interests or personal relationships that could have appeared to influence the work reported in this paper.

\section{Acknowledgments}

This study was funded by the São Paulo Research Foundation (FAPESP - grant \#2018-00016-8), European Commission (EBW+ program), and National Council for Scientific and Technological Development $(\mathrm{CNPq})$. The authors thank Companhia Energética de Minas Gerais S.A. (CEMIG), Agência Nacional de Águas (ANA), Instituto Nacional de Meteorologia (INMET), and Câmara de Comercialização de Energia Elétrica (CCEE) for kindly providing the data needed to carry out this research. The authors also thank the developers of RS Minerve, computational tool utilized in this research, and Espaço da Escrita - Pró-Reitoria de Pesquisa (PRP/UNICAMP), for the language services provided.

\section{References}

ANA (2020a). "National water agency”. Monitoring Sao Francisco river basin. http://a rquivos.ana gov.br/saladesituacao/BoletinsDiarios/SF 25-1-2017.pdf Mar. 26, 2020

ANA (2020b). "National water agency". Hidroweb software. http://www.snirh.gov.br/ hidroweb/apresentacao Mar. 26, 2020.

ANEEL (2019). "National agency of electric energy". Generation information system SIGA. https://bit.ly/2IGf4Q0 Mar. 26, 2020.

Bergstrom, S. (1992). The HBV model - its structure and applications. SMHI Reports RH, No. 4, Norrkoping.

Boehlert, B., Strzepek, K. M., Gebretsadik, Y., Swanson, R., McCluskey, A., Neumann, J. E., ... Martinich, J. (2016). Climate change impacts and greenhouse gas mitigation effects on U.S. hydropower generation. Applied Energy, 183(2016), 1511-1519.

Caruso, B. S., King, R., Newton, S., \& Zammit, C. (2017). Simulation of climate change effects on hydropower operations in mountain headwater lakes, New Zealand. River Res. Applic., 33, 147-161 (2017).

CBHSF (2020). "River basin committee". Main characteristics of the basin. http://cbhsa ofrancisco.org.br/a-bacia/ Mar. 26, 2020.

CCEE (2020a). Electric energy trading chamber. Settlement Price of Differences (SPD). https://www.ccee.org.br/portal/faces/pages_publico/o-que-fazemos/como_ccee_a tua/precos/metodologia_de_precos?_afrLoop $=2163230320883848$ adf.ctrl-state $=$ owws0cr09_112\#!\%40\%40\%3F_afrLoop\%3D216323032088384\%26_adf.ctrl-state\% 3Dowws0cr09_116 Apr. 20, 2020.

CCEE (2020b). "Electric energy trading chamber". Hidroedit.exe for Hidr.dat. https:// www.ccee.org.br/portal/faces/pages_publico/o-que-fazemos/como_ccee_atua/ precos/deck_de_precos?_afrLoop $=215628905096068 \&$ adf.ctrl-state $=$ owws0cr09_ 50\#!\%40\%40\%3F_afrLoop\%3D215628905096068\%26_adf.ctrl-state\%3Dowws0cr09_ 54 Mar. 26, 2020.

CEMIG (2020a). Companhia Energética de Minas Gerais. http://www.cemig.com.br/enus/Pages/default.aspx Mar. 26, 2020.

CEMIG (2020b). "Companhia Energética de Minas Gerais". Três Maria hydroelectric plant daily data. https://www.cemig.com.br/pt-br/a_cemig/nossos_negocios/usinas/Pagina s/Tr\%C3\%AAs_Marias_dados.aspx Mar. 26, 2020.

CEMIG (2020c). “Companhia Energética de Minas Gerais”. Três Maria hydroelectric plant information. https://novoportal.cemig.com.br/usina/usina-hidreletrica-de-tres-maria s/ Oct. 11, 2020.

CEMIG (2020d). "Companhia Energética de Minas Gerais". Climate change. http://www. cemig.com.br/pt-br/A_Cemig_e_o_Futuro/sustentabilidade/Documents/CDP/CDP_\% 20Mudan\%C3\%A7as_clim\%C3\%A1ticas_2017_Versao-final.pdf Oct. 11, 2020.

CHESF (2020). Companhia Hidrelétrica do São Francisco. https://www.chesf.gov.br/ SistemaChesf/Pages/SistemaGeracao/Sobradinho.aspx Oct. 11, 2020.

Deval Castillo, J., Luengo García, J. A., Lorenzo Riera, J. L., García, H. J., \& de Paz García, M. (2011). Módulo nival en los modelos hidrológicos de la Confederación Hidrográfica del Cantábrico. Calibración y validación en Picos de Europa. Jornada Internacional del Agua Barcelona, España. ISBN-13: 978-84-615-4023-5. http://www.ingenieria delagua.com/2004/JIA/Jia2011/pdf/p525.pdf 2020. Oct. 11, 2020.

García Hernández, J., Boillat, J. -L., Feller, I., \& Schleiss, A. J. (2013). Présent et futur des prévisions hydrologiques pour la gestion des crues. Le cas du Rhône alpin. Mémoire de la Société vaudoise des Sciences naturelles, 25, 55-70.

Gaudard, L., Gabbi, J., Bauder, A., \& Romerio, F. (2016). Long-term uncertainty of hydropower revenue due to climate change and electricity prices. Water Resources Management, 30, 1325-1343 (2016). 
Gaudard, L., Romerio, F., Valle, F. D., Gorret, R., Maran, S., Ravazzani, G., ... Volonterio, M. (2014). Climate change impacts on hydropower in the Swiss and Italian Alps. Science of the Total Environment, 493(2014), 1211-1221.

Gebre, S., Boissy, T., \& Alfredsen, K. (2014). Sensitivity to climate change of the thermal structure and ice cover regime of three hydropower reservoirs. Journal of Hydrology, 510(2014), 208-227.

Haguma, D., Leconte, R., Côté, P., Krau, S., \& Brissette, F. (2014). Optimal hydropower generation under climate change conditions for a northern water resources system. Water Resources Management, 28, 4631-4644 (2014).

Harrison, G. P., Whittington, H. W., \& Wallace, A. R. (2003). Climate change impacts on financial risk in hydropower projects. IEEE Transactions on Power Systems, 18(4), 1324-1330.

Hidalgo, I. G., Fontane, D. G., Soares, F. S., Cicogna, M. A., \& Lopes, J. E. G. (2010). Data consolidation from hydroelectric plants. Journal of Energy Engineering, 136(3), 87-94

INMET (2020). "National Institute of Meteorology". Meteorological database for teaching and research. http://www.inmet.gov.br/projetos/rede/pesquisa/ Mar. 26, 2020.

Jahandideh-Tehrani, M., Haddad, O. B., \& Loáiciga, H. A. (2015). Hydropower reservoirmanagement under climate change: the Karoon Reservoir system. Water Resources Management, 29, 749-770 (2015).

Kopytkovskiy, M., Geza, M., \& McCray, J. E. (2015). Climate-change impacts on water resources and hydropower potential in the Upper Colorado River Basin. Journal of Hydrology: Regional Studies, 3(2015), 473-493.

Kosa, P. (2009). Air temperature and actual evapotranspiration correlation using Landsat 5 TM satellite imagery. Kasetsart Journal (Natural Science), 43, 605-611.

Lerner, G. L. S. (2006). Hydro-generation impacts in the São Francisco river due to the diversion project of its water using the net flow mathematical model acquanet. Master dissertation Brazil: Federal University of Rio de Janeiro.

Liu, X., Tang, Q., Voisin, N., \& Cui, H. (2016). Projected impacts of climate change on hydropower potential in China. Hydrology and Earth System Sciences, 20, 3343-3359.

Lobanova, A., Koch, H., Liersch, S., Hattermann, S. F., \& Krysanova, V. (2016). Impacts of changing climate on the hydrology and hydropower production of the Tagus River basin. Hydrol. Process., 30, 5039-5052 (2016).

Lujano Laura, E., Sosa Sarmiento, J. D., Lujano Laura, A., \& Lujano Laura, R. (2016). Semidistributed hydrological modeling in the Titicaca hydrographic region: case study of the Ramis river basin, Peru. Journal of High Andean Research, 18(4), 431-438.

Lumbroso, D. M., Woolhouse, G., \& Jones, L. (2015). A review of the consideration of climate change in the planning of hydropower schemes in sub-Saharan Africa. Climatic Change, 133, 621-633 (2015).

Madani, K., Guégan, M., \& Uvo, C. B. (2014). Climate change impacts on high-elevation hydroelectricity in California. Journal of Hydrology, 510(2014), 153-163.

Maran, S., Volonterio, M., \& Gaudard, L. (2014). Climate change impacts on hydropower in an alpine catchment. Environmental Science \& Policy, 43(2014), 15-25.

Minerve, R. S. (2020). Documentation - Technical Manual. https://www.crealp.ch/fr/a ccueil/le-crealp/telechargement-doc/category/173-manuels-utilisateur.html? download=219:rs-minerve-technical-manual.

Mohor, G. S., Rodriguez, D. A., Tomasella, J., \& Siqueira, J. L., Jr. (2015). Exploratory analyses for the assessment of climate change impacts on the energy production in an Amazon run-of-river hydropower plant. Journal of Hydrology: Regional Studies, 4(2015), $41-59$.

Park, J. Y., \& Kim, S. J. (2014). Potential impacts of climate change on the reliability of water and hydropower supply from a multipurpose dam in South Korea. Journal of the American Water Resources Association, 50(5), 1273-1288 (2014).
Porto, N. A. (2016). Probabilistic pricing of power generation assets: focus on renewable energy sources in the context of auctions and mechanisms. Ph.D. thesis São Paulo, Brazil: State Univ. of Campinas.

Sample, J. E., Duncan, N., Ferguson, M., \& Cooksley, S. (2015). Scotland's hydropower: current capacity, future potential and the possible impacts of climate change. Renewable and Sustainable Energy Reviews, 52(2015), 111-122.

Sánchez, A., \& Izzo, M. (2017). (2017). "Micro hydropower: an alternative for climate change mitigation, adaptation, and development of marginalized local communities in Hispaniola Island". Climatic Change, 140, 79-87.

Schaeffer, R., Lucena, A. F. P., Costa, I. V. L., Vásquez, E., Viviescas, C., \& Huback, V. (2018). Climate change and the energy sector in Brazil. In C. Nobre, J. Marengo, \& W. Soares (Eds.), Climate change risks in Brazil (pp. 143-179). Cham: Springer. https://doi.org/ 10.1007/978-3-319-92881-4_6.

Schaeffer, R., Szklo, A., Lucena, A. F. P., Soria, R., \& Chávez-Rodriguez, M. (2013). The vulnerable Amazon. IEEE Power E Energy Magazine p, 23-31.

Shrestha, S., Bajracharya, A. R., \& Babel, M. S. (2016). Assessment of risks due to climate change for the upper tamakoshi hydropower project in Nepal. Climate Risk Management, 14(2016), 27-41.

Silveira, C. S., Souza Filho, F. A., Lopes, J. E. G., Barbosa, P. S. F., \& Tiezzi, R. O. (2014) Analysis of flow projections in Brazilian basins with hydroelectric power plants using data from the IPCC -AR4 for the 21st century. Rev. Bras. de Rec. Hidr., 19(4), 59-71.

Silveira, C. S., Souza Filho, F. A., Martins, E. S. P. R., Oliveira, J. L., Costa, A. C., Nobrega, M. T., ... Silva, R. F. V. (2016). Climate change in the São Francisco river basin: analysis of precipitation and temperature. Rev. Bras. Rec. Hid, 21(2), 416-428.

Soito, J. L. S., \& Freitas, M. A. V. (2011). Amazon and the expansion of hydropower in Brazil: Vulnerability, impacts and possibilities for adaptation to global climate change. Renewable and Sustainable Energy Reviews, 15(2011), 3165-3177.

Spalding-Fecher, R., Joyce, B., \& Winkler, H. (2017). Climate change and hydropower in the Southern African Power Pool and Zambezi River Basin: System-wide impacts and policy implications. Energy Policy, 103(2017), 84-97.

Tarroja, B., Aghakouchak, A., \& Samuelsen, S. (2016). Quantifying climate change impacts on hydropower generation and implications on electric grid greenhouse gas emissions and operation. Energy, 111(2016), 295-305.

Thornthwaite, C. W. (1948). An approach toward a rational classification of climate Geography Review, 38(1), 55-94.

Tiezzi, R. O., Barbosa, P. S. F., Lopes, J. E. G., Zambon, R. C., \& Francato, A. L. (2014). Scenarios simulation for climate change and their impacts on hydropower generation. 90 Internationational Congress of Bioenergy, 01-03/10/2014. São: Paulo/SP - Brazil.

Timalsina, N. P., Alfredsen, K. T., \& Killingtveit, A. (2015). Impact of climate change on ice regime in a river regulated for hydropower. Can. J. Civ. Eng., 42, 634-644 (2015).

Tobin, C., Nicotina, L., Parlange, M. B., Berne, A., \& Rinaldo, A. (2011). Improved Interpolation of Meteorological Forcings for Hydrologic applications in a Swiss Alpine Region. Journal of Hydrology, 401(1-2), 77-89.

Wang, B., Liang, X. -J., Zhang, H., Wang, L., \& Wei, Y. -M. (2014). Vulnerability of hydropower generation to climate change in China: results based on Grey forecasting model. Energy Policy, 65(2014), 701-707. 